\title{
Removal of Organic Content and Color from Secondary Treated Wastewater in Reference with Toxic Potential of Ozone During Ozonation
}

\section{Smriti Tripathi ${ }^{1}$, Devendra Mani Tripathi ${ }^{2}$ and B D Tripathi ${ }^{1 *}$}

${ }^{1}$ Centre for Environmental Science \& Technology, Banaras Hindu University, Varanasi, 221005, India

${ }^{2}$ Pollution Ecology Research Laboratory, CAS Botany, Banaras Hindu University, Varanasi-221005, India

\begin{abstract}
Present study was conducted to evaluate the impact of ozonation on the quality improvement of Secondary Treated wastewater at Varanasi, in India. Physico- chemical parameters such as BOD, COD, TOC, UV ${ }_{254}$, color and microbiological parameters such as E. coli, fecal coli. \& total coliform disinfection parameters were used to evaluate the efficiency of ozone to upgrade secondary effluent quality. Experimental results revealed that $10 \mathrm{mgL}^{-1} \mathrm{O}_{3}$ for 5 minutes exposure duration was found most suitable dose and contact time for the significant reduction of physicochemical parameters of secondary treated wastewater such as BOD, COD, TOC, UV ${ }_{254}$ and color i.e. $30 \%, 14.3 \%$ $45 \%$ \& $60 \%$ respectively as well as it enhanced the biodegradability more than $50 \%$ in the treated water. Our data also revealed that this applied dose and exposure time is responsible for the highest degradation of microbiological parameters i.e. $>98 \%$. Other than this the toxic response of test species was influenced mainly by the dose and exposure time. The acute toxic effect after ozonation was observed on V. fischeri and found that toxic effect of the secondary effluent was decreased after applied dose and exposure duration. Results supported the expectation that the process of Ozone might enhance the overall treatment efficiency of secondary effluent treatment.
\end{abstract}

Keywords: Ozonation; Biodegradable organic carbon; Secondary treated wastewater; Physico-chemical Properties; Toxicity

\section{Introduction}

Water is considered to be the most import pillar of modern civilization in all aspect of life so the presence of harmful organic compounds and pathogenic microorganisms in the water increases the magnitude of water pollution on human health and livelihoods [1-4]. The increasing pressures of wastewater discharge on water supplies and the shortage of water resources, more and more attentions have been paid on the proper treatment of wastewater [5-7].

The conventional and advanced treatment processes (i.e. microfiltration (MF) or ultra-filtration (UF) technology) are wellknown but due to large land occupation, complicated operation, sophisticated management and its higher cost cannot be widely used [7-9]. Growing concerns about the environment have resulted in the development of new environment friendly higher treatment efficiency and cost effective technologies, to minimize the problem of wastewater $[7,10,11]$.

Now a day ozone is used worldwide and has been largely applied in the treatment of wastewater [12]. Ozone, a highly oxidative agent, react directly or via a hydroxyl radical mechanism results into the reduction of organic content with increase of biodegrability of natural organic matter and the efficient inactivation of a wide range of microorganisms [6,13-15]. Ozonation has been used to meet discharge requirements for coliform and virus inactivation since the 1970s [16]. Frequent Ozonation for treatment of wastewater and drinking water is due to its ability to oxidize complex organic molecules, phenols, Endocrine Disruptive Chemicals (EDCs) and pharmaceuticals [17-21]. In combination of microbial disinfection make ozonation an attractive alternative for advanced wastewater treatment [22].

Earlier, corona discharge was the main source for the generation of Ozone, which requires much higher resource and economy for the treatment of water with ozone. So, it was limited to certain areas viz UV lights for the drinking water treatment. Due to aforesaid reasons it was not only feasible for treatment of municipal sewage. Recent ozone generation techniques viz UV lights require lower energy consequently; costs are also reduced making the field application of Ozonation economically viable $[23,24]$.

In order to estimate the overall environmental impact of ozonated wastewaters, several studies have been conducted incorporating bioassays along with physicochemical and microbiological determinations [25]. Ecotoxicological testing provides an overall direct estimation of the environmental hazard of effluents, by the exposure of selected test species on the respective samples and the determination of certain end-points, such as lethal effect, growth ability, etc. Therefore, bioassays consist of an attractive and promising alternative and can be performed supplementary to chemical determinations for the assessment of the environmental impact of effluents the corresponding results were variable and depended on both the nature of the test and the aquatic sample characteristics [26-28] indicated that the toxic responses of ozonated secondary effluents on the survival and reproduction of Ceriodaphnia dubia were site-specific and presented seasonal variation (ozonation conditions: $1-3 \mathrm{mgL}^{-1}$ ozone dose for 10 min., followed by $5 \mathrm{~min}$. of residual ozone exposure). Similar results have been reported by Monarca et al. [20], who studied the effect of ozonated secondary effluents (at specific optimized ozonation conditions concerning certain microbiological parameters) on bacteria Vibrio fischeri. Nakamuro et al. [21], Ono et al. [22] and Takanashi et

*Corresponding author: B D Tripathi, Centre for Environmental Science \& Technology, Banaras Hindu University, Varanasi, U.P, 221005, India, E-mail: smrititripathibhu@gmail.com

Received November 28, 2010; Accepted March 01, 2011; Published April 22, 2011

Citation: Tripathi S, Tripathi DM, Tripathi BD (2011) Removal of Organic Content and Color from Secondary Treated Wastewater in Reference with Toxic Potential of Ozone During Ozonation. Hydrol Current Res 2:111. doi:10.4172/21577587.1000111

Copyright: ( 2011 Tripathi S, et al. This is an open-access article distributed under the terms of the Creative Commons Attribution License, which permits unrestricted use, distribution, and reproduction in any medium, provided the original author and source are credited. 
al. [24] found that ozone treatment was effective for the removal of waste or surface water mutagen precursors. India has emerged as a fast developing nation resulting rapid industrialization and urbanization. This has imposed a serious threat of water pollution manifold and renders the effluent unsuitable for disposal into surface water stream [3]. Although numerous workers have reported about the positive impact of ozonation on treatment of secondary effluent [7,31,32]. However, in tropical cities especially in India there is lack of study on toxic potential of ozone during ozonation of secondary effluent.

Henceforth, present study was conducted with the following objectives:

a). To treat organic components of the wastewater using ozonation

b). To treat microbial biomass present in the wastewater using ozonation

c). To examine the toxic properties of secondary effluents before and after ozonation.

\section{Material and Methods}

\section{Study area}

Present study was conducted in Varanasi city $\left(82^{\circ} 15^{\prime} \mathrm{E}\right.$ to $83^{\circ} 30^{\prime}$ $\mathrm{E}$ and $24^{\circ} 35^{\prime} \mathrm{N}$ to $25^{\circ} 30^{\prime} \mathrm{N}$ ). It was estimated that approximately 275 million liters per day (MLD) wastewater is generated in the city out of which only 122 MLD is treated and remaining 153 MLD untreated wastewater is discharged into the river Ganga. Three sewage treatment plants are established in the city, located at Dinapur, Bhagwanpur and Diesel Locomotive Works (DLW) with the treatment capacities of 100 MLD, 12 MLD and 10 MLD respectively. These treatment plants utilize conventional Activated Sludge Process for the treatment. Secondary treated sewage from Bhagwanpur Sewage Treatment Plant was used in this study. The secondary effluent is alkaline in nature and contains high amount of organic content.

\section{Sample collection}

Samples were collected in plastic containers from the effluent channel and transferred to the laboratory, preserved and stored for further analytical determinations and treatment. Biological activity such as microbial respiration, chemical activity such as precipitation or $\mathrm{pH}$ change, and physical activity such as aeration or high temperature must be kept to a minimum. The length of time that a constituent in wastewater will remain stable was related to the character of the constituent and the preservation method used $[25,26]$.

\section{Experimental Unit}

The experimental set-up of the ozonation process is depicted in Figure 1. Ozonation experiments were performed in a laboratory batch column reactor, consisted of a $200 \mathrm{~cm}$ height cylindrical tube with a 4 $\mathrm{cm}$ internal diameter. A Schott ceramic porous diffuser (porosity 4,10 $16 \mathrm{~mm}$ ) was placed in the bottom of the reactor for ozone distribution. Compressed, dried atmospheric air, at a flow rate of $3 \mathrm{Lmin}^{-1}$, was used for the production of ozone by an ozone generator (Model HINDCO). Ozone concentration in the gas phase was measured using the iodometric method [25]. The concentration of ozone in the feed gas was determined prior to the experiments and $2.0 \mathrm{mg} / \mathrm{L}$ - $15.0 \mathrm{mg} / \mathrm{L}$ ozone dosages were applied. The applied ozone dose was higher, as compared to the transferred ozone dose, implying that the used iodometric method was rather inaccurate for the determination of transferred ozone dose, especially when high ozone doses for long durations were fed into the reactor [32]. Therefore, the applied ozone

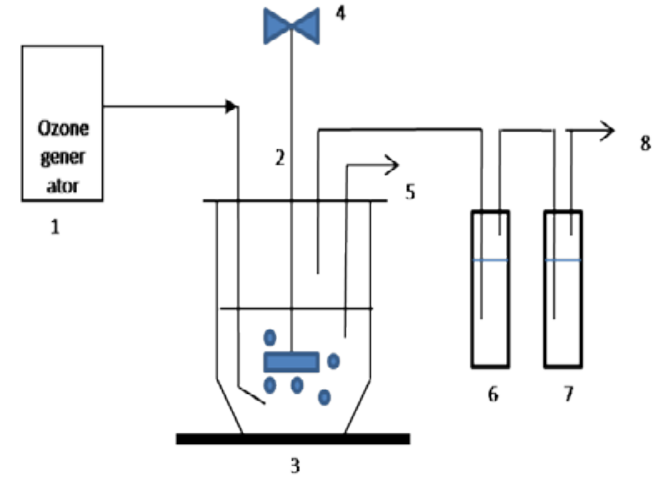

Figure 1: Experimental setup for ozonation (1) ozone generator (HINDCO), (2) stirrer (3) reactor with point sparger and stirrer and air vent, (4) motor (5) sample port, (6) first gas washing trap $(2 \% \mathrm{KI}),(7)$ second gas washing trap (20\% KI). (8) Air.

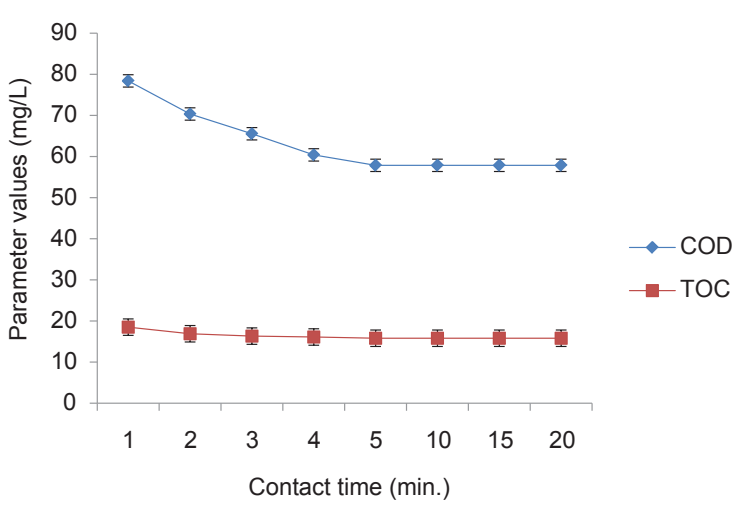

Figure 2: The removal of TOC \& COD by ozonation at a fixed ozone dose $\left(10 \mathrm{mgL}^{-1}\right)$ and at different contact time.

dose was used for reporting the results of this study. All experiments were performed at room temperature using $1 \mathrm{~L}$ sample applying the respective reaction contact times of 2 to $20 \mathrm{~min}$. The sample was aerated for $5 \mathrm{~min}$. to remove residual ozone (removal was confirmed by residual ozone measurements) to avoid the toxic effect of dissolved ozone on the effluents.

\section{Analytical Methods}

\section{Physicochemical parameters}

Secondary effluent and treated samples were subjected to certain common analytical determinations, including biochemical oxygen demand (BOD), chemical oxygen demand (COD), total organic carbon (TOC), color and $\mathrm{UV}_{254}$.

The concentration of ozone was monitored with the two methods. The absolute ozone amount in the inlet and outlet gas streams was determined with titration method [25] using Potassium Iodide and $\mathrm{Na}_{2} \mathrm{~S}_{2} \mathrm{O}_{3}$. The residual ozone in liquid phase was directly determined at $258 \mathrm{~nm}$ using a Shimadzu UV spectrophotometer. The absorbance values for ozone were converted in concentration units using a molar absorption coefficient for ozone $3000 \mathrm{M}^{-1} \mathrm{~cm}^{-1}$. The comparison of the above two methods indicated that they had the same precision. Chemical Oxygen Demand (COD) and color were determined with closed reflux micro methods and Pt-Co standard colorimetric method, 
respectively. For Color estimation a series of Pt-Co color standard solutions were prepared and determined consequently using UV spectrophotometer at $420 \mathrm{~nm}$. Then, a linear regression equation of absorbance against color was obtained: $Y=0.0004 X+0.0021$ with an $R^{2}$ of 0.9998 . ( $Y$ is the absorbance and $X$ is the color value. The valid range of color was recorded between 0 to $100^{\circ}$ ).

$\mathrm{UV}_{254}$ was determined with Shimadzu UV spectrophotometer. For TOC determination samples were filtered through $0.45 \mu \mathrm{m}$ membrane. After determining the initial TOC samples were kept at $20^{\circ} \mathrm{C}$ for 5 days to analyze the Biodegradable Organic Carbon (BDOC). After 5 days incubation at $20^{\circ} \mathrm{C}$ the samples were again filtered using 0.45 $\mu \mathrm{m}$ membrane. The difference between initial and final values of TOC was considered as the BDOC of the water, while the turbidity of the samples was measured using a turbidity meter (Lab-Vis, Aqualytic). Other parameters such as temperature, dissolved Oxygen (DO) and $\mathrm{pH}$ were analyzed using standard methods described in APHA, 2005.

\section{Microbiological parameters}

These samples were also examined for microbiological analysis. Total coliforms, fecal coliforms, and E. coli, were analyzed using the method of the Most Probable Number [26].

\section{Samples concentration procedure}

Treated and untreated samples of $2 \mathrm{~L}$ distilled water were concentrated by adsorption on $\mathrm{C} 18$ cartridges for the $V$. fischeri acute toxicity test, according to method 525.2 [25]. The wastewater sample of 2L was filtered through $0.45 \mathrm{~mm}$ cellulose membrane filter and acidified at $\mathrm{pH} 2$ by addition of $6 \mathrm{~N} \mathrm{HCl}$ solutions [25]. After that samples were passed through appropriate tri functional C18 cartridges (Sep-pak Plus tC18 Environmental Cartridges, Waters, 0.9 g), pre-activated by organic solvents, in the following order: $5 \mathrm{~mL}$ ethyl acetate (Merck), $5 \mathrm{~mL}$ methylene chloride (Panreac), $10 \mathrm{~mL}$ methanol (Merck) and 10 $\mathrm{mL}$ distilled water. Consecutively, the cartridges were eluted by $5 \mathrm{~mL}$ of ethyl acetate followed by $5 \mathrm{~mL}$ of methylene chloride. Finally, $1 \mathrm{~mL}$ of dimethylsulfoxide (DMSO, Merck) was added for solvent exchanging and the eluate was concentrated to the final volume of $1 \mathrm{~mL}$ in a slightly warm water bath, under a gentle stream of nitrogen.

\section{Toxicity testing}

The toxicity of concentrated wastewater samples were evaluated using the marine luminescence bacteria $V$. fischeri originally in freezedried form and activated prior to use by the appropriate reconstitution solution. In addition, a control sample of DMSO was examined for toxic

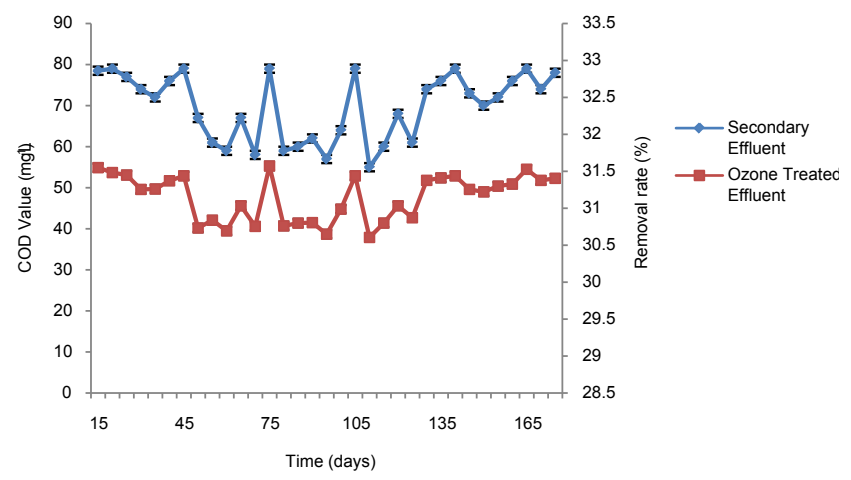

Figure 3: The removal of COD by ozonation (exposure dose $=10 \mathrm{mgL}^{-1}$ and contact time $=5 \mathrm{~min}$.)

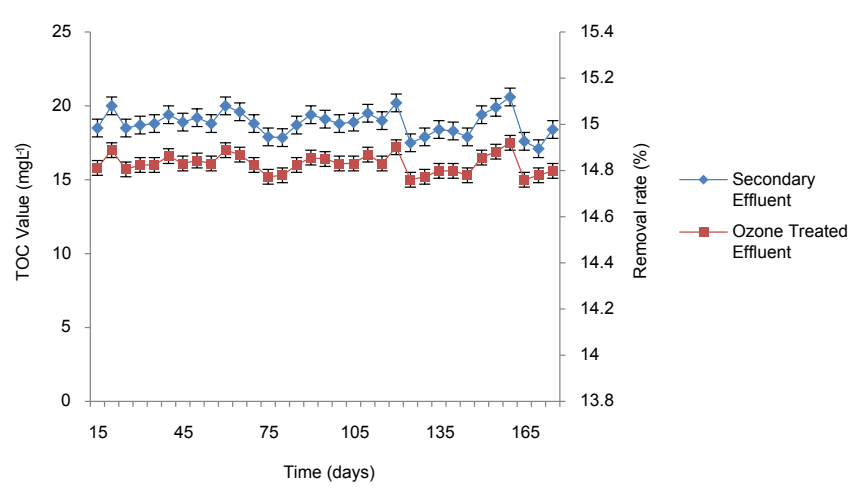

Figure 4: The removal of TOC by ozonation (exposure dose $=10 \mathrm{mgL}^{-1}$ and contact time $=5 \mathrm{~min}$.).

effects against $V$. fischeri, at concentrations corresponding to those of tested wastewater samples. For the examination of each concentrated sample toxicity by Microtox, various dilutions of each matrix were prepared by using the appropriate quantities of a $22 \% \mathrm{NaCl}$ Osmotic Adjustment Solution (OAS), provided by SDI, for salinity adjustment to $2 \%$ according to the standard Microtox Protocol procedure. The $\mathrm{ICF}_{50}$ values (concentration factor of sample that caused 50\% inhibition on the bioluminescence of test organism) were calculated.

\section{Data analysis}

Descriptive statistics and correlation analysis were carried out using the SPSS 16 software.

\section{Results and Discussion}

\section{Degradation of organic content from the secondary treated wastewater}

The degradation of organic content from the secondary treated wastewater by Ozonation processes was studied for six months. The results are shown in Figure 3. During present experiment about 25$30 \%$ reduction in COD values has been recorded.

The original TOC of the secondary treated wastewater ranged from 15-20 $\mathrm{mgL}^{-1}$ (Figure 4). Ozonation has revealed an enhancement of $14.3 \%$ over the initial value of the TOC.

The removal of $\mathrm{UV}_{254}$ and color of the secondary treated wastewater are shown in Figure 5 and Figure 6 respectively. The $\mathrm{UV}_{25}$ represents the organic matters with $\mathrm{C}=\mathrm{C}, \mathrm{C}=\mathrm{O}$ structures, which have strong absorbance at $254 \mathrm{~nm}$. Examples are phenolic, poly aromatic hydrocarbons (PAHs), aromatic ketone, and aromatic aldehyde etc. In general, these compounds have phenyl structures. Ozonation efficiently removes $45 \% \mathrm{UV}_{254}$ and $60 \%$ color. This is clear from the result that $\mathrm{C}=\mathrm{C}, \mathrm{C}=\mathrm{O}$ structural groups of organics are destroyed by Ozone. Therefore, from present experiment it is proved that Ozonation increases the removal rate of $\mathrm{UV}_{254}$ and color from the wastewater.

\section{Effect of ozonation on biodegradability of the secondary treated wastewater}

BDOC indicates biodegradable organic matter in wastewater. For any level of $\mathrm{BOD}$ and $\mathrm{COD}$ that resulted in $\mathrm{BOD} / \mathrm{COD}$ ratio of more than 0.1 is classified as biodegradable organic matter. The effect of Ozonation on BDOC is shown in Figure 7. It can be seen that the BDOC values were increased from initial value is $0.8-1.1 \mathrm{mgL}^{-1}$ to $1.25-1.42$ $\mathrm{mgL}^{-1}$ by Ozonation within 5 minutes contact time at an Ozone dose 
of $10 \mathrm{mgL}^{-1}$, that is, $56 \%$ improvement was realized. This result also indicated that Ozonation can significantly improve the biodegradability of the secondary effluent, in other words, the biochemical treatment efficiency can be improved by Ozonation.

\section{Effect of ozone on microorganism in ozonized secondary effluent}

Microbiological analysis was performed on the ozone-disinfected samples for the determination of biological factors and the results are presented in Table 1, for the two different ozone dosages (5.0, 10.0 and $15.0 \mathrm{mg} \mathrm{O} / \mathrm{L}$ respectively). The completed ozonation assays indicated that there was a significant increase in total coliform and E. coli. inactivation when the dosage was increased and the contact time did not have a significant effect on total coliform and $E$. coli. inactivation. The differences between the mean inactivation values were statistically significant $(\mathrm{P}=0.05)$ which verified that a lower dosage can achieve almost the same results.

The present study reveals that, Total Coliform, Fecal Coliform and E.Coli. were substantially removed around $98 \%$ after disinfection of samples, using an ozone concentration of $10.0 \mathrm{mg} \mathrm{O}_{3} / \mathrm{L}$ for $5 \mathrm{~min}$ exposure time as shown in Table 1.

\section{Effect of ozonation on $\mathrm{pH}$ and Temperature of the Secondary treated wastewater}

The $\mathrm{pH}$ of the secondary effluent slightly increases and no significant effect was found on the temperature. $\mathrm{pH}$ and temperature

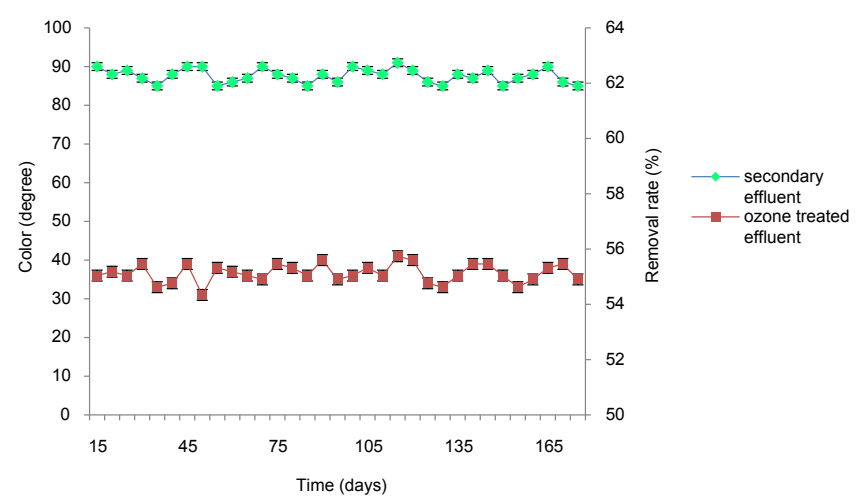

Figure 5: The removal of color by ozonation (exposure dose $=10 \mathrm{mgL}^{-1}$ and contact time $=5 \mathrm{~min}$.).

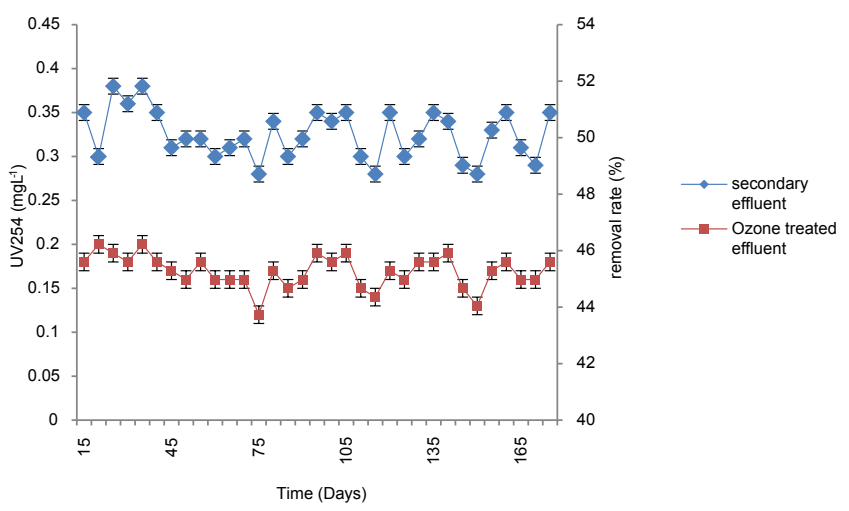

Figure 6: The removal of $\mathrm{UV}_{254}$ by ozonation (exposure dose $=10 \mathrm{mgL}^{-1}$ and contact time $=5 \mathrm{~min}$.)

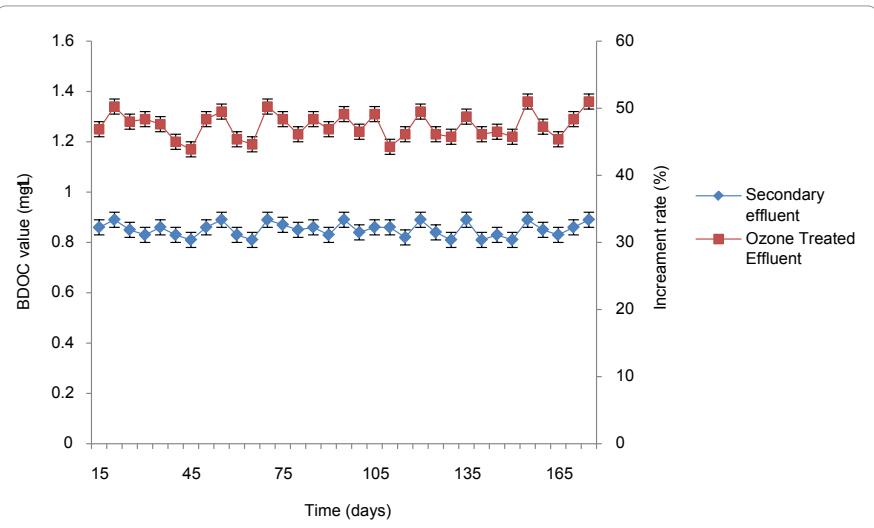

Figure 7: The Increase in BDOC value by ozonation (exposure dose $=10 \mathrm{mgL}^{-}$ and contact time $=5 \mathrm{~min}$.).

values in secondary treated wastewater also influences the removal of pollutants [28-31] present investigation revealed that the optimum temperature and higher $\mathrm{pH}$ values favor the oxidation of organic content. Low temperature may increase Ozone solubility and beneficial for production of hydroxyl radicals. However, it decreases the reaction rate. Higher $\mathrm{pH}$ values can stimulate Ozone to self-decompose and generate more hydroxyl radicals.

\section{Effect of ozone on test organism in secondary effluent}

The investigation of toxicity of concentrated samples towards bacteria $V$. fischeri was considered as an indirect method for estimating chronic toxicity. The time exposure was $2 \mathrm{~min}-10 \mathrm{~min}$, in order to evaluate the effect of exposure time on the response of bacteria. The toxic response after $5 \mathrm{~min}$. exposure and the corresponding 0.05 level of significance are depicted in Figure 8. The results are expressed as $\mathrm{ICF}_{50}$, which is the concentration factor of a sample that caused $50 \%$ inhibition of the emitted bioluminescence of the bacteria. The initial concentration factor of each sample was 2000 , since $2000 \mathrm{~mL}$ were concentrated to the final volume of $1 \mathrm{~mL}$. The bacteria were exposed to several dilutions of each concentrated sample and the $\mathrm{ICF}_{50}$ values were calculated by the obtained dose-response curves. A control sample of distilled water was treated exactly as the tested samples, in order to investigate the potential positive toxic effects due to applied pre-concentration procedure. The control sample did not show any toxic effect at the examined concentrations. As shown in Figure 8, the toxicity of ozonated samples depended mainly on ozone dose and exposure time. In general, toxicity reduction was observed only at low ozone doses, whereas the application of higher ozone doses resulted in slight increase of toxicity. The $\mathrm{ICF}_{50}$ of raw secondary effluent was 75 and was increased to about 140 after ozonation with $2.5 \mathrm{mgL}^{-1}$ of $\mathrm{O}_{3}$ for $10 \mathrm{~min}$. An increase of ozone dose to values higher than 2.5 $\mathrm{mgL}^{-1}$ resulted in the augmentation of toxic response of bacteria for short periods of processing. However, prolonged ozonation process induced stabilization of toxic responses to $\mathrm{ICF}_{50}$ values higher than the corresponding values of raw effluent. The $\mathrm{ICF}_{50}$ of samples ozonated for 5 min. using $10.0 \mathrm{mgL}^{-1}$ of $\mathrm{O}_{3}$ was about 36 at $5 \mathrm{~min}$ exposure time and increased to about 78 after $10 \mathrm{~min}$. of reaction time. The results revealed that the toxicity of ozone in the wastewater does not increase significantly at the provide ozone dose of $10.0 \mathrm{mgL}^{-1}$ at the contact time of $5 \mathrm{~min}$.

In general, the toxicity results of this study implied the formation of intermediate ozonation products that induced inhibition of bacteria luminescence; these intermediate products depended strongly on 
Citation: Tripathi S, Tripathi DM, Tripathi BD (2011) Removal of Organic Content and Color from Secondary Treated Wastewater in Reference with Toxic Potential of Ozone During Ozonation. Hydrol Current Res 2:111. doi:10.4172/2157-7587.1000111

Page 5 of 6

\begin{tabular}{|c|c|c|c|c|c|c|c|c|c|c|}
\hline \multirow{3}{*}{ Bacterial population } & \multirow{3}{*}{ Secondary Effluent } & \multicolumn{9}{|c|}{ Applied ozone doses } \\
\hline & & \multicolumn{3}{|c|}{$5 \mathrm{mgL}^{-1}$} & \multicolumn{3}{|c|}{$10 \mathrm{mgL}^{-1}$} & \multicolumn{3}{|c|}{$15 \mathrm{mgL}^{-1}$} \\
\hline & & $2 \mathrm{~min}$. & $5 \mathrm{~min}$. & $10 \mathrm{~min}$. & $2 \mathrm{~min}$. & $5 \mathrm{~min}$. & $10 \mathrm{~min}$. & $2 \mathrm{~min}$. & $5 \mathrm{~min}$. & $10 \mathrm{~min}$. \\
\hline $\begin{array}{l}\text { Total coliform } \\
(M P N / 100 \mathrm{ml})\end{array}$ & 254000 & 540000 & 19000 & 12000 & 14000 & 900 & 600 & 500 & 400 & 400 \\
\hline Fecal coliform (MPN/100 ml) & 209000 & 209000 & 15000 & 8900 & 9900 & 600 & 500 & 450 & 400 & 300 \\
\hline E. Coli (MPN/100 ml) & 210000 & 210000 & 16000 & 9500 & 8400 & 600 & 400 & 200 & 200 & 200 \\
\hline
\end{tabular}

Table 1: Microbial analysis of secondary effluent treated at various ozone dosage and reaction times.

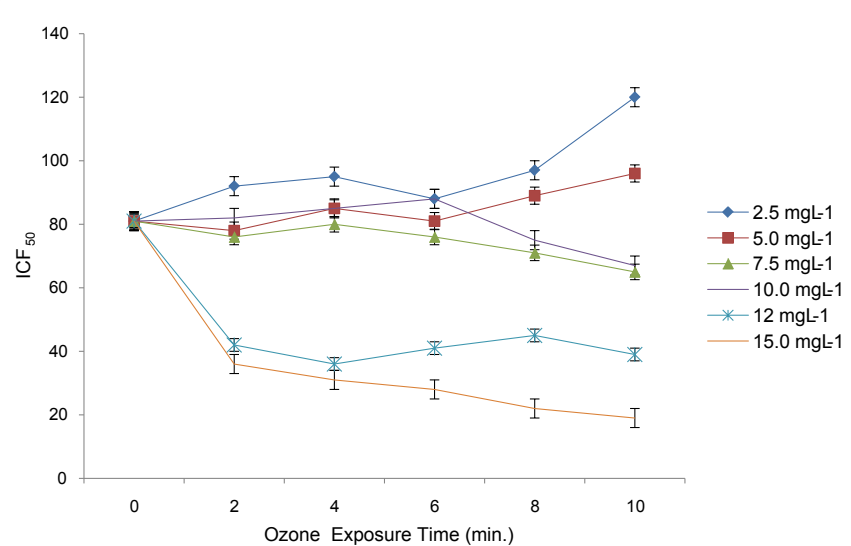

Figure 8: Toxic response of $V$. fischeri by ozonated secondary effluents at different ozone dosage and contact time.

ozonation conditions. In addition, it can be concluded that low ozone doses and prolonged ozonation caused reduction of toxicity. Results obtained from other studies are rather conflicting and indicate that ozonation may either increase or decrease the toxicity of samples. Monarca et al. [20] found that toxicity modification of ozonated urban wastewaters depended significantly upon the characteristics of the raw samples. The toxicity of summer samples was increased after ozonation ( $\mathrm{ICF}_{50}$ was decreased), whereas the toxicity of winter samples was significantly decreased (4-5-fold ICF $_{50}$ increase) after ozonation using similar treatment conditions. In this study, it is shown that the treatment conditions influenced the toxicity of ozonated samples, possibly as a result of the formation of by-products. Indeed, a toxicity increase was observed in certain samples, although a reduction was observed in the values of the physicochemical parameters. The toxic effects of high ozone doses could be attributed to by-products that might be formed during the reaction of ozone with the residual pollutants, presented in the reclaimed wastewaters in trace concentrations [33]. It should be also stressed that although almost complete removal of the microorganisms was achieved and high removal rate of certain pollutants were observed, when using the highest ozone dose, the reclaimed water might cause significant adverse effects on aquatic life, according to the results of these bioassays.

\section{Conclusions}

Present study revealed that at the applied ozone dose of $10 \mathrm{mgL}^{-1}$ for $5 \mathrm{~min}$. shows a significant reduction in physico - chemical parameter and biological biomass from secondary treated wastewater. The physico - chemical parameters include COD, TOC, $\mathrm{UV}_{254}$, and color shows a reduction of $30 \%, 15 \%, 45 \%$ and $60 \%$ respectively and biological biomass of E. Coli, Total coliform and F. coli reduced upto $>99 \%$. Results also show that at this ozone dose and exposure duration ozonation can enhance the biodegradability of the secondary effluent by improving BDOC value about $45-50 \%$. The study of toxicity of pre-concentrated samples showed that the applied ozone dose and exposure duration doesn't increase the toxicity in the secondary treated wastewater. Thus in totality according to the present study Ozone exposure indicates quality improvement of the secondary treated municipal wastewater.

\section{Acknowledgement}

The authors are thankful to CEST (Centre for Environmental Science and Technology), Banaras

Hindu University, Varanasi-221005, for providing facilities for the study.

\section{References}

1. Yavich AA, Lee KH, Chen KC, Pape L, Masten SJ (2004) Evaluation of biodegradability of NOM after ozonation Water Res 38:2839-2846.

2. Saroj DP, Kumar A, Bose P, Tare V, Dhopavkar Y (2005) Mineralization of some natural refractory organic compounds by biodegradation and ozonation Water Res 39:1921-1933.

3. Gardner EA, Morton D, Sands J, Matthews P, Cook FJ, et al. (2001) The filter system for tertiary treatment of sewage effluent by land application, its performance in a subtropical environment. Water Sci Technol 43: 335-342.

4. Liberti L, Notarnicola M (1999) Advanced treatment and disinfection for municipal wastewater reuse in agriculture. Wat Sci Technol 40: 235-245.

5. Wang S, Jun MA, Liu B, Yifeng J, Zhang H (2008) Degradation characteristics of secondary effluent of domestic wastewater by combined process of ozonation and bio filtration. J Hazard Mater 150: 109-114.

6. Bao HZ, Ding YW, Wang BZ, Wang L (2005) Advanced treatment comprehensive utilization of urban wastewater. China Water and Wastewater 21: $10-13$.

7. Gottschalk C, Libra JA, Saupe A (2000) Ozonation of Water and Wastewater: A Practical Guide to Understanding Ozone and its Application; Wiley- VCH: London, UK.

8. Rice RG (1997) Application of ozone for industrial wastewater treatment: a review Ozone Sci. Eng 18: 477-515.

9. Zwiener C, Frimmel FH (2000) Oxidative treatment of pharmaceuticals in water Water Res 34: 1881-1885.

10. Huber MM, Gobel A, Joss A, Hermann N, Loffler D, et al. (2005) Oxidation of pharmaceuticals during ozonation of municipal wastewater effluents: a pilot study. Environ Sci Technol 39: 4290-4299.

11. Snyder SA, Wert EC, Rexing DJ, Zegers RE, Drury DD (2006) Ozone oxidation of endocrine disruptors and pharmaceuticals in surface water and wastewater Ozone. Sci Eng 28: 445-460.

12. Kim I, Tanaka H (2010) Use of ozone-based processes for the removal of pharmaceuticals detected in a wastewater treatment plant. Water Environ Res 82: 294-301.

13. Tripathi S, Pathak V, Tripathi DM, Tripathi BD (2011) Application of Ozone Based Treatments of Secondary Effluents In The Tropical Cities Bioresource Technology 102: 2481-2486.

14. Wert Eric C, Rosario-Ortiz FL, Drury DD, Snyder SA (2007) Formation of oxidation by products of wastewater. Water Research 4: 1481-1490.

15. Freire RS, Kunz A, Durán N (2001). Remediation and toxicity removal from Kraft E1 paper mill effluent by ozonization. Environ Technol 21: 897-904.

16. Jennifer GA, Marc WB, Douglas RC, Allison MF (2010) Effects of oxygenation on ammonia oxidation potential and microbial diversity in sediment from surface-flow wetland mesocosms. Bioresour Technol 101: 1389-1392.

17. Manusadzianas L, Balkelyte L, Sadauskas K, Blinova I, Pollumaa L, et al. (2003) 
Citation: Tripathi S, Tripathi DM, Tripathi BD (2011) Removal of Organic Content and Color from Secondary Treated Wastewater in Reference with Toxic Potential of Ozone During Ozonation. Hydrol Current Res 2:111. doi:10.4172/2157-7587.1000111

Ecotoxicological study of Lithuanian and Estonian wastewaters: selection of the biotests and correspondence between toxicity and chemical based indices. Aquat Toxicol 63: 27-41.

18. Zoeteman BC, Hrubec JJ, Greef ED, Kool HJ (1982) Mutagenic activity associated with by-products of drinking water disinfection by chlorine, chlorine dioxide, ozone and UV-irradiation Environmental Health Perspectives 46: $197-$ 205.

19. Blatchley ER III, Hunt BA, Duggirala R, Thompson JE, Zhao J, et al. (1997) Effects of disinfectants on wastewater effluent toxicity. Water Research 31: 1581-1588.

20. Monarca S, Feretti D, Collivignarelli C, Guzzella L, Zerbini I, et al. (2000) The influence of different disinfectants on mutagenicity and toxicity of urban wastewater. Water Research 34: 4261-4269.

21. Nakamuro K, Ueno $H$, Sayato $Y$ (1989) Mutagenic activity of organic concentrates from municipal river water and sewage effluent after chlorination or ozonation. Water Science and Technology 21: 1895-1898.

22. Ono Y, Somiya I, Kawamura M, Uenishi K (1992) Genotoxicity of organic substances in municipal sewage and its ozonated products. Water Science and Technology 22: 501-517.

23. Xu, P, Janex ML, Savoye P, Cockx A, Lazarova V (2002) Wastewater disinfection by ozone: main parameters for process design. Water Research 36: 1043-1055.

24. Takanashi H, Mayumi M, Kato M, Hirata M, Hano T (2002) Removal of mutagen precursor from wastewater by activated sludge and oxidation treatment. Water Science and Technology 46: 389-394.

25. Agustina TE, Ang HM, Vareek VK (2005) A review of synergistic effect of photocatalysis and ozonation on wastewater treatment. J Photochem Photobiol C: $264-273$.

26. Yang C, Xu YR, Teo KC, Goh NK, Chia LS, et al. (2004) Destruction of organic pollutants in reusable wastewater using advanced oxidation technology. Chemosphere 59: 441-445

27. USEPA (2003) Long Term 2 Enhanced Surface Water Treatment Rule Toolbox Guidance Manual (DRAFT). EPA 815-D-03-009.

28. Environmental Protection Agency (1982) Handbook for Sampling and Sample Preservation of Water and Wastewater. EPA 600/4 - $82-029$.

29. APHA (2005) Standard Methods for Water and Wastewater Examination, 21st Ed, American Public Health Association, Washington.

30. Petala M, Samaras P, Zouboulis A, Kungolos A, Sakellaropoulos GP (2006) Ecotoxicological properties of effluents treated using tertiary methods. Environmental Toxicology 21: 417-424.

31. Coca M, Pen M, Gonza'lez G (2005) Variables affecting efficiency of molasses fermentation wastewater ozonation. Chemosphere 60: 1408-1415.

32. Beltran FJ (2004) Kinetics of the ozonation of wastewaters, in: Ozone Reaction Kinetics for Water and Wastewater Systems. Lewis Publishers Boca Rat'on Florida pp113-150.

33. Bijan L, Mohseni M (2005) Integrated ozone and bio treatment of pulp mill effluent and changes in biodegradability and MSD of organic compounds. Water Res 39: pp3763-3772.

34. Wang XD, Wang L, Liu Y, Duan WS (2007) Ozonation pretreatment for ultra filtration of the secondary effluent. J Membr Sci 287: pp187-191. 